Eur Surg 2018 $\cdot 50: 285-298$

https://doi.org/10.1007/s10353-018-0545-x Received: 14 December 2017

Accepted: 7 June 2018

Published online: 20 July 2018

(c) The Author(s) 2018

CrossMark

Punkte sammeln auf ...

\section{SpringerMedizin.at}

Das DFP Literaturstudium ist Teil des Diplom-Fortbildungs-Programms (DFP) der Österreichischen Ärztekammer und ermöglicht qualitätsgesicherte Fortbildung durch das Studium von Fachartikeln nach den Richtlinien des DFPs.

Teilnahmemöglichkeiten:

\section{DFP Punkte Online, per Post, Fax}

\section{oder eMail}

Der Multiple-Choice-Fragebogen des

DFP kann bis zum jeweils angegebenen Datum eingereicht werden:

- Online: Für eingeloggte User steht der Beitrag und der Fragebogen auf unserer Website unter http://www.springermedizin.at/fortbildung/zur Verfügung.

- per Post: Prinz-Eugen-Straße 8-10, 1040 Wien

- per Fax: +431 1302426

- per eMail (eingescannter Test) an: susanna.hinterberger@springer.at

\section{Approbation}

Diese Fortbildungseinheit wird mit 3 DFP Punkten approbiert. Die Fortbildungspunkte werden rasch und unkompliziert mit Ihrer ÖÄK-Nummer elektronisch verbucht.

\section{Kontakt und weitere}

\section{Informationen}

Springer-Verlag GmbH

Springer Medizin

Susanna Hinterberger

E-Mail: susanna.hinterberger@springer.at SpringerMedizin.at
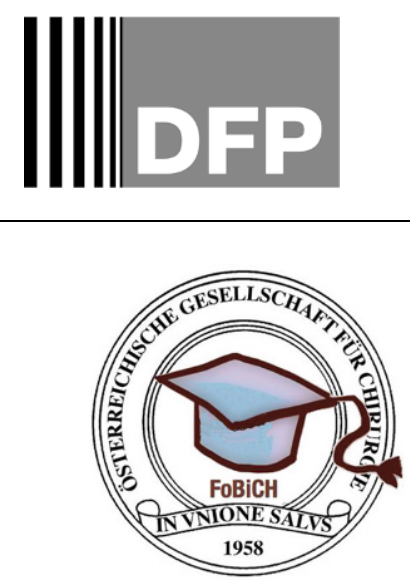

\section{DFP}

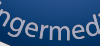

Margot Fodor ${ }^{1}$. Florian Primavesi ${ }^{1}$ Dagmar Morell-Hofert ${ }^{2}$ - Matthias Haselbacher ${ }^{3}$. Eva Braunwarth ${ }^{1}$ - Benno Cardini ${ }^{1}$ - Eva Gassner ${ }^{2}$ - Dietmar Öfner ${ }^{1} \cdot$ Stefan Stättner ${ }^{1}$ ${ }^{1}$ Department of Visceral, Transplantation and Thoracic Surgery, Medical University of Innsbruck, Innsbruck, Austria

${ }^{2}$ Department of Radiology, Medical University of Innsbruck, Innsbruck, Austria

${ }^{3}$ Department of Trauma Surgery, Medical University of Innsbruck, Innsbruck, Austria

\title{
Non-operative management of blunt hepatic and splenic injuries-practical aspects and value of radiological scoring
}

\section{systems}

Inhalt

Learning objectives

Introduction

Background

Objective

Classification of liver and splenic trauma

Trauma scoring systems

Success and failure of non-operative manage-

\section{ment}

Physical and clinical examination

Intensity and duration of monitoring

Haemoglobin measurement

Number of transfused blood units

Hospital discharge and ICU admission

Bed rest and return to activity

Oral intake
Prophylaxis of thromboembolic events Post-splenectomy and post-embolisation vaccination

Repeat imaging

Practical conclusion

\section{Ärztlicher Fortbildungsanbieter:}

Fortbildungsakademie der Österreichischen Gesellschaft für Chirurgie

\section{Lecture Board}

Heinz Wykypiel, Medizinische Universität Innsbruck

Christoph Ebenbichler, Universitätsklinik für Innere Medizin I Innsbruck 


\title{
Non-operative management of blunt hepatic and splenic injuries-practical aspects and value of radiological scoring systems
}

\author{
Abstract \\ Background. Non-operative management (NOM) of blunt hepatic and splenic injuries has become \\ popular in haemodynamically stable adult patients, despite uncertainty about efficacy, patient se- \\ lection, and details of management. Up-to-date strategies and practical recommendations are pre- \\ sented. \\ Methods. A selective literature search was conducted in PubMed and the Cochrane Library \\ (1989-2016). \\ Results. No randomized clinical trial was found. Non-randomized controlled trials and large retro- \\ spective and prospective series dominate. Few systematic reviews and meta-analyses are available. \\ NOM of selected patients with blunt liver and spleen injuries is associated with low morbidity and \\ mortality. Only data of limited evidence are available on intensity and duration of patient moni- \\ toring, repeat imaging, antithrombotic prophylaxis and return to normal activity. There is high- \\ level evidence on early mobilisation and post-splenectomy vaccination. \\ Conclusion. NOM of blunt liver or spleen injuries is a worldwide trend, but the literature does not \\ provide high-grade evidence for this strategy.

\section{Keywords} \\ Abdominal trauma $\cdot$ Sports $\cdot$ Multiple trauma $\cdot$ Classification $\cdot$ Diagnostic imaging
}

\section{Main novel aspects}

- This continuing education article describes the current state of the art of NOM of blunt hepatic and splenic injuries.

- Practical clinical recommendations are presented.

- Proposed injury scales are reviewed.

\section{Learning objectives}

\section{After reading this article, you should ... \\ - understand the rational for NOM blunt hepatic and splenic injuries. \\ - be able to apply the criteria for appropriate patient selection.}

\section{Zusammenfassung}

Hintergrund. Das nichtoperative Management (NOM) stumpfer Leber- und Milzverletzungen hat sich zu einem beliebten Verfahren bei hämodynamisch stabilen Patienten entwickelt, trotz der Ungewissheit bezüglich Wirksamkeit, Patientenselektion und Details zum Management. In diesem Beitrag werden aktuelle Verfahren und praktische Empfehlungen vorgestellt.

Methoden. Eine selektive Literaturrecherche in PubMed und Cochrane Library (1989-2016) wurde durchgeführt.

Ergebnisse. Es wurde keine randomisierte klinische Studie gefunden. Nichtrandomisierte kontrollierte Studien und große retrospektive und prospektive Serien dominieren das Ergebnis. Einzelne systematische Reviews und Metaanalysen sind verfügbar. Das NOM bei ausgewählten Patienten mit stumpfen Leber- und Milzverletzungen ist mit einer geringen Morbidität und Mortalität assoziiert. Hinsichtlich der Intensität und Dauer der Patientenüberwachung, der wiederholten Bildgebung, Thromboseprophylaxe und Wiederaufnahme der normalen Aktivitäten stehen nur Daten mit eingeschränkter Evidenz zur Verfügung. Es besteht eine hochgradige Evidenz für die frühe Mobilisation und die Immunisierung nach Splenektomie.

Schlussfolgerung. Das NOM stumpfer Leber- und Milzverletzungen ist ein weltweiter Trend, jedoch bietet die Literatur keine hochgradige Evidenz für dieses Verfahren.

\section{Schlüsselwörter}

Bauchtrauma $\cdot$ Sport $\cdot$ Multiple Traumata $\cdot$ Klassifikation $\cdot$ Diagnostische Bildgebung 


\section{- be familiar with the strengths and weaknesses of current classification and scoring systems for injuries of the liver and spleen.}

- be able to critically discuss the role of $\mathrm{CT}$ in guiding hepatic and splenic injury management.

- know the therapeutic strategies for NOM, including details of monitoring and followup.

- understand the importance of post-splenectomy and post-embolisation vaccination.

\section{Introduction}

Blunt abdominal trauma is very common in central European emergency departments, especially due to sports activities. Management of these injuries can be challenging because of the frequent association with a complex clinical picture of abdominal, thoracic, limb and head trauma $[1,2]$.

\section{Background}

\section{Therapeutic strategies}

Abdominal organs are involved in $30 \%$ of polytrauma patients, with an occurrence of hepatic and splenic injuries in 13 and 16\%, respectively [3]. Therapeutic strategies contain either nonoperative management (NOM) including radiological interventions (angiography), or surgical treatment. Due to frequent postoperative complications after primary surgical treatment in the past, a paradigm shift to NOM in haemodynamically stable patients has emerged in major trauma centres [3, 4], where NOM has been described as a safe procedure when twenty-four-seven availability of experienced surgeons, modern imaging modalities, intensive care units (ICU) and other support services [5] is assured.

This shift was largely driven by intraoperative observations that found many minor liver and splenic injuries to no longer be bleeding $[2,6,7]$, with no further surgical intervention necessary. NOM is associated with lower hospital costs, fewer non-therapeutic laparotomies, a lower rate of intra-abdominal complications, lower rates of blood transfusion, and decreased morbidity and mortality $[8,9]$.

\section{Patient selection criteria}

The decision to employ a NOM pathway for blunt hepatic and splenic injuries requires the patient to meet several criteria, primarily that of haemodynamic stability. Although many of the developed algorithms and institutional protocols addressing NOM of splenic injuries include contraindications such as advanced patient age, higher splenic injury grades and distinct transfusion triggers, the lion's share of these factors are more individualized algorithms than strict, scientifically evidenced conventions. The recent 2012 edition of the Eastern Association for the Surgery of Trauma (EAST) guidelines for the management of blunt hepatic injuries are comparable to those for blunt splenic injuries, with the possibility of adjunct interventions including angiography, endoscopic retrograde cholangiopancreatography (ERCP) and laparoscopy [10]. Haemodynamically unstable patients or those affected by peritonitis still warrant operative intervention. However, many questions regarding practical aspects of NOM are still without conclusive answers in the guidelines, despite the large amount of recent literature on this topic. For example, there are few clear recommendations regarding the following aspects: frequency of clinical examination, imaging procedures and haemoglobin measurements; intensity and duration of monitoring; transfusion triggers after which operative or angiographic intervention should be considered; time to re-initiating oral intake; duration and intensity of restricted activity during hospitalisation and after discharge; optimum length of stay (LOS) within the ICU and hospital; timing of initiating venous thromboembolic prophylaxis; the role of post-splenic injury vaccines and post-discharge follow-up [11].

\section{Objective}

This summary focuses on current state-of-the-art practical management recommendations, including a review of proposed injury scales. Grades of evidence are based on the approvals of the Oxford Centre for Evidence-Based Medicine [12, 13].
Haemodynamically stable patients are nowadays frequently managed non-operatively

Many minor hepatic und splenic injuries were intraoperatively found to require no further surgical intervention

Haemodynamically instable patients or those with peritonitis warrant operative intervention 


\begin{tabular}{|c|c|c|}
\hline Grade $^{a}$ & Type & Injury description \\
\hline \multirow[t]{2}{*}{ I } & Haematoma & Subcapsular, $<10 \%$ surface area \\
\hline & Laceration & Capsular tear, $<1 \%$ parenchymal depth \\
\hline \multirow[t]{2}{*}{ II } & Haematoma & Subcapsular, $10-50 \%$ surface area, intra-parenchymal $<5 \mathrm{~cm}$ in diameter \\
\hline & Laceration & Capsular tear, $1-3 \mathrm{~cm}$ parenchymal depth that does not involve a trabecular vessel \\
\hline \multirow[t]{2}{*}{ III } & Haematoma & $\begin{array}{l}\text { Subcapsular, }>50 \% \text { surface area or expanding; ruptured subcapsular or parenchymal haematoma, intra- } \\
\text { parenchymal haematoma } \geq 5 \mathrm{~cm} \text { or expanding }\end{array}$ \\
\hline & Laceration & $>3 \mathrm{~cm}$ parenchymal depth or involving trabecular vessels \\
\hline IV & Laceration & Laceration involving segmental or hilar vessels producing major devascularisation ( $>25 \%$ of spleen) \\
\hline \multirow[t]{2}{*}{ V } & Laceration & Complete shattered spleen \\
\hline & Vascular & Hilar vascular injury which devascularises spleen \\
\hline
\end{tabular}

\section{Advanced imaging techniques en- able new radiological classification systems}

\section{Scaling systems measure lesion severity and facilitate clinical} decisions

\section{The Moore score is a gold standard for spleen and liver injuries}

\section{Success rates of NOM of hepatic trauma range from 82 to $100 \%$}

Even high-grade hepatic and splenic lesions in haemodynamically stable patients can be treated successfully with NOM

\section{Classification of liver and splenic trauma}

An accurate classification system forms the basis for the clinical decision-making process. Advances in imaging techniques have led to the development of newer radiological classification systems; however, the accuracy of these remains to be validated [14]. Despite their widespread acceptance and use, these gradings have been subjected to limited independent studies, and only a few of the scales have been validated for outcomes on a large-scale basis [15].

\section{Trauma scoring systems}

Trauma scores were introduced more than 30 years ago for assigning numerical values to anatomic lesions and physiological changes after an injury. The purpose of a scaling system for specific injuries is to measure lesion severity and provide a common language to facilitate clinical decisions [16]. In view of the complex clinical picture and variety of treatment options, any modern classification scheme for trauma should be able to fulfil a series of general principles:

- First of all, it should be able to identify the mechanism of trauma, as well as the extent and anatomic details of the injuries.

- Second, it should be able to recognize distinctive groups of injuries, which could be correlated with a certain management strategy, either conservative or surgical.

- Third, the grades of trauma should be linked with the likelihood of further complications and potential outcome.

- Finally, any classification has to be objective and reproducible, and must have prospective as well as retrospective applicability [14].

\section{AAST Score}

The most accepted scoring system is the "Moore score" (AAST Score), based on the Organ Injury Scale (OIS) of the American Association for Surgery of Trauma (AAST) published in 1989 [17]. The Moore score is considered a gold standard to describe spleen and liver injuries [18]. This classification scheme is an anatomic description scaled from I to $\mathrm{V}$ for the spleen and from I to VI for the liver, representing minimal to the most severe injury (• Tables 1 and 2; $[12,17]$ ). Most liver injuries are grade I, II or III, and are successfully treated conservatively. In contrast, the majority of grade IV, V or VI liver injuries necessitate operative intervention. The success rate of NOM of hepatic trauma ranges from 82 to $100 \%[19,20]$. Similarly, in splenic injury, lowAAST-grade lesions (I-III) are frequently treated with NOM, facilitating good results in terms of morbidity and mortality [13]. However, many patients with even high-grade lesions of the liver or spleen may be haemodynamically stable and treated successfully with $\operatorname{NOM}[13,19]$ in specialised centres. Hence, a contemporary NOM algorithm for splenic and hepatic injuries should also consider the haemodynamic status and other associated injuries, e.g. through incorporation of the Injury Severity Score (ISS).

The primary objective of the AAST classification was to provide a common language to describe specific organ injuries and facilitate clinical decision-making. The OIS committee of AAST was organized in 1987 with the purpose of developing injury severity scales for individual organs. 


\begin{tabular}{|c|c|c|}
\hline Grade $^{a}$ & Type & Injury description \\
\hline \multirow[t]{2}{*}{ I } & Haematoma & Subcapsular, $<10 \%$ surface area \\
\hline & Laceration & Capsular tear, $<1 \mathrm{~cm}$ parenchymal depth \\
\hline \multirow[t]{2}{*}{ II } & Haematoma & Subcapsular, $10-50 \%$ surface area, intra-parenchymal $<10 \mathrm{~cm}$ in diameter \\
\hline & Laceration & $1-3 \mathrm{~cm}$ parenchymal depth, $<10 \mathrm{~cm}$ in length \\
\hline \multirow[t]{2}{*}{ III } & Haematoma & $\begin{array}{l}\text { Subcapsular, }>50 \% \text { surface area or expanding; ruptured subcapsular or parenchymal haematoma, intra-parenchy- } \\
\text { mal haematoma } \geq 10 \mathrm{~cm} \text { or expanding }\end{array}$ \\
\hline & Laceration & $>3 \mathrm{~cm}$ parenchymal depth \\
\hline IV & Laceration & Parenchymal disruption involving $25-75 \%$ of hepatic lobe or $1-3$ Couinaud's segments within the single lobe \\
\hline \multirow[t]{2}{*}{ V } & Laceration & Parenchymal disruption involving $>75 \%$ of hepatic lobe or $>3$ Couinaud's segments within the single lobe \\
\hline & Vascular & Juxtavenous hepatic injuries, i.e. retrohepatic vena cava/central major hepatic veins \\
\hline VI & Vascular & Hepatic avulsion \\
\hline
\end{tabular}

The first OIS grading systems for spleen, liver and kidney were published in 1988. A study performed by Tinkoff et al. [15] attempted to validate the OIS score for spleen, liver and kidney injuries using the National Trauma Data Bank. Injuries were stratified by each organ either as an isolated injury or in combination with other intra-abdominal or extra-abdominal injuries. For all groups, each OIS grade was then analysed for mortality, hospital LOS, duration of ICU stay and hospital costs. For patients with combined abdominal injuries, higher OIS rates were associated with an increase in mortality, organ-specific operative rate and hospital costs. Also, when isolated organ injuries were examined, increasing OIS grade significantly correlated with these outcome variables [15].

The introduction and refinement of CT scanning has had a great impact on the classification and subsequent management of spleen and liver trauma. CT scanning is able to identify subcapsular or central haematomas, contusions, periportal tracking of fluid as well as complex lacerations and fragmentations.

\section{Other proposed CT-based classifications}

Despite the AAST classification incorporating extensive preoperative assessment data derived from the CT examination, additional CT-based classification schemes were developed. Mirvis et al. proposed a five-grade CT-based scheme of hepatic injury varying from capsular avulsion to major parenchymal damage and vascular injury [8]. However, the current scoring systems do not incorporate the localization of injury and the mechanism of trauma [18]. Hence, the role of CT grading of blunt abdominal injuries is still controversial. Some authors investigated whether CT findings can determine whether patients require surgery or can be managed conservatively. Retrospective studies evaluated CT grading of splenic injuries and supported the hypothesis that properly selected patients can be safely observed, regardless of the magnitude of splenic injury on CT scans. A decision to undergo early surgical exploration should be based on clinical criteria, including the patient's age and associated injuries [21]. This is also underlined by findings of Sutyak et al., noticing that CT may be inaccurate for estimating the severity of adult splenic injury. This group compared CT results with operative findings and analysed outcome of NOM as well as CT reproducibility accordingly. The CT score correctly predicted intraoperative grade in 10 patients, underestimated it in 18 and overestimated it in 6. Splenic injury was missed in 5 patients. Radiologists disagreed on $20 \%$ of the scans. In conclusion, splenic injury management should not be based solely on CT severity and on CT-based scoring systems [22]. In another study, abdominal CT scans obtained on admission were retrospectively reviewed over a 3-year period. CT-based injury scores were compared with clinical outcome in patients treated either surgically or conservatively. The results indicated that even major hepatic injury assessed with preoperative $\mathrm{CT}$ can usually be managed without surgery in haemodynamically stable patients [18].

In summary, an accurate clinical classification of hepatic and splenic injuries correctly determining the appropriate treatment strategy as well as predicting subsequent outcome is still pending [14]. In the majority of cases, scoring is only related to the degree of injury to a particular
Modern CT techniques have had a huge impact on the classification and management of splenic and hepatic trauma

The decision for early surgical exploration should be based on clinical criteria 
Extra vigilance is warranted during non-operative management of patients with trauma to both liver and spleen

\section{Thorough physical examination is very important for determining the necessity of exploratory laparotomy}

Repeated clinical examination combined with modern imaging and laboratory investigations plays a key role in clinical decision-making organ, while the outcome depends not only on injury to a single organ, but rather on the totality of all injuries and the patient's existing morbidities.

Therefore, most centres will rely on algorithms combining different parameters such as haemodynamic stability, imaging findings and timely availability of interventional techniques to decide whether to opt for immediate surgery or attempt NOM.

\section{Success and failure of non-operative management}

Contradictory findings are reported concerning prognostic factors for failure of NOM in blunt abdominal trauma. In a survey performed by Olthof et al., the Delphi method was used to reach consensus among 30 expert trauma surgeons and interventional radiologists for the NOM of patients with blunt splenic injuries. An agreement of $80 \%$ or greater was defined as consensus. Results indicated that awareness for unsuccessful NOM is required in patients aged 40 years or older, in patients with an ISS of 25 or higher, or those with splenic injury grade III or higher [23].

Blunt trauma patients with concomitant injury to liver and spleen have higher ISS and an increase in mortality, LOS and transfusion requirements. Hence, the risk of failure with NOM is increased and extra vigilance is therefore warranted when choosing this form of therapy in the presence of injury to both organs [24]. In a retrospective protocol-driven study performed by Hsieh et al., a failure rate of $4.9 \%$ was described [25]. Other parameters that might be helpful in predicting the failure of NOM are lactate levels on admission, necessity of transfusion, crystalloid resuscitation and drop-in haematocrit levels during the first hour after admission [26].

Strict protocols for follow-up of patients treated with NOM are essential. According to Peitzman et al., only one third of trauma centres have well-established NOM protocols for spleen injuries [27]. Only $20 \%$ of experts from the AAST consider that the protocol established in their institution is well supported by the available literature [28].

\section{Physical and clinical examination}

The value of physical examination is often underestimated, but increased temperature or respiratory rate can indicate an intra-abdominal perforation or the presence of an abscess. Pulse and blood pressure can also change with sepsis, intra-abdominal bleeding or peritonitis. A carefully performed physical examination remains one of the most important methods to determine the need for exploratory laparotomy [29]. The initial clinical assessment is often difficult and inaccurate. Tenderness and spasm caused by associated injuries in the abdominal wall may make diagnosis challenging. Abdominal wall injury contributes to clinical error in diagnosing injury of the intra-abdominal viscera but more importantly, free peritoneal blood may cause peritoneal irritation. Several studies have highlighted the issues related to physical examination in blunt abdominal trauma. In a retrospective analysis performed by Schurink et al., physical examination was shown to be possibly unreliable in assessing abdominal organ involvement in patients with multiple injuries or isolated head injuries [30]. Also, while most conscious patients with severe intra-abdominal injuries will usually present with either abdominal pain or tenderness, there is a small group of awake and alert patients in whom the physical examination will be falsely negative due to associated extra-abdominal injuries [31]. However, repeated clinical examination supplemented with modern imaging and laboratory investigations plays a key role in reaching therapeutic decisions, thus preventing unnecessary laparotomies. If the decision has been made to observe the patient, repetitive physical evaluations are needed, which also increases accuracy. Therefore, close clinical follow-up is a basic principle of NOM and should be repeated frequently during the hospital stay [3]. An overview of available data on recommendations for clinical examination as well as on other issues discussed below is given in - Tables 3 and 4.

\section{Intensity and duration of monitoring}

Monitoring of vital parameters most commonly includes at least blood pressure, heart rate, pulse oximetry and respiratory rate. NOM of hepatic and splenic injuries consists of a period of inhospital or ICU observation and monitoring. What remains unclear is the duration of necessary observation and the frequency of these interventions [10, 11]. Many clinical studies do not specify the duration of monitoring. In a 10-year review, Raza et al. evaluated vital signs for the first $72 \mathrm{~h}$. In this study, NOM was successful in $89.91 \%$ of 1071 patients, where 108 patients showed signs of ongoing haemorrhage, delayed evidence of hollow viscous perforation or intra- 
Table 3 Advice on different practical issues of NOM arising during hospitalisation after blunt hepatic and splenic injuries

\begin{tabular}{|c|c|c|c|c|c|c|c|}
\hline & Day 1 & Day 2 & Day 3 & $\begin{array}{l}\text { Day } 3 \rightarrow \text { hospital } \\
\text { discharge }\end{array}$ & Comment & References & $\begin{array}{l}\text { Highest } \\
\text { grade of } \\
\text { evidence }\end{array}$ \\
\hline $\begin{array}{l}\text { Physical and } \\
\text { clinical exami- } \\
\text { nation }\end{array}$ & Every $4 \mathrm{~h}$ & Every $4 \mathrm{~h}$ & Every $4 \mathrm{~h}$ & Every $12 \mathrm{~h}$ & $\begin{array}{l}\text { Recommended for all grades of } \\
\text { injuries every } 4 \text { h until day } 3 \text { and } \\
\text { daily until discharge }\end{array}$ & {$[3,29,30]$} & $2 a$ \\
\hline $\begin{array}{l}\text { Intensity/ } \\
\text { duration of } \\
\text { monitoring }\end{array}$ & Continuously & Continuously & Continuously & Every $12 \mathrm{~h}$ & $\begin{array}{l}\text { Recommended for grade I-VI } \\
\text { injuries during the first } 3 \text { days }\end{array}$ & {$[3,8]$} & $2 a$ \\
\hline $\begin{array}{l}\text { Haemoglobin } \\
\text { measurement }\end{array}$ & Every $6 \mathrm{~h}$ & Every $6 \mathrm{~h}$ & Every $12 \mathrm{~h}$ & Every $24 \mathrm{~h}$ & $\begin{array}{l}\text { Recommended, every } 6-12 \mathrm{~h} \\
\text { during the first three days, } \\
\text { followed by monitoring every } \\
24 \mathrm{~h} \text { until discharge }\end{array}$ & {$[9,14,23]$} & $2 a$ \\
\hline Bed rest & $\begin{array}{l}\text { Suggested } \\
\text { for grade I-VI } \\
\text { lesions }\end{array}$ & $\begin{array}{l}\text { Suggested } \\
\text { for } \\
\text { grade I-VI } \\
\text { lesions }\end{array}$ & $\begin{array}{l}\text { Mobilisation } \\
\text { sug- } \\
\text { gested for } \\
\text { grade I-VI } \\
\text { lesions }\end{array}$ & $\begin{array}{l}\text { Mobilisation } \\
\text { suggested for } \\
\text { grade I-VI lesions }\end{array}$ & $\begin{array}{l}\text { Mobilisation is recommended } \\
\text { between second and third day } \\
\text { after injury in haemodynamic } \\
\text { stable patients }\end{array}$ & {$[32,33]$} & $2 b$ \\
\hline Repeat imaging & $\begin{array}{l}\text { Not routinely, } \\
\text { only in case of } \\
\text { deterioration } \\
\text { of the pa- } \\
\text { tient's general } \\
\text { condition }\end{array}$ & $\begin{array}{l}\text { Ultrasound } \\
\text { for } \\
\text { grade I-VI } \\
\text { lesions }\end{array}$ & Not routinely & $\begin{array}{l}\text { Ultrasound for } \\
\text { grade I-VI lesions } \\
\text { each second day } \\
\text { until discharge }\end{array}$ & $\begin{array}{l}\text { Ultrasound instead of CT scans } \\
\text { is suggested in young patients, } \\
\text { based on clinical judgment. } \\
\text { Routine follow-up CT scanning } \\
\text { should not be part of NOM pro- } \\
\text { tocols for blunt liver and splenic } \\
\text { injuries. Most experts suggest } \\
\text { ultrasound monthly after dis- } \\
\text { charge for } 6 \text { months (grade I-VI } \\
\text { lesions); a single CT scan is rec- } \\
\text { ommended } 6 \text { months after } \\
\text { discharge (lesions grade I-VI) }\end{array}$ & {$[34,35,36]$} & $2 b$ \\
\hline $\begin{array}{l}\text { DVT prophy- } \\
\text { laxis }\end{array}$ & No & No & Yes & Yes & Suggested $48 \mathrm{~h}$ after trauma & {$[37,38]$} & $2 a$ \\
\hline Oral intake & No & Yes & Yes & Yes & $\begin{array}{l}\text { Allowed } 24 \mathrm{~h} \text { after trauma in } \\
\text { haemodynamically stable pa- } \\
\text { tients }\end{array}$ & [29] & $2 a$ \\
\hline
\end{tabular}

abdominal infection requiring laparotomy [3]. Fernandes et al. developed a rigid protocol for NOM of grade IV splenic injuries. Monitoring consisted of haemoglobin measurement every 6 and arterial blood gas measurement every $12 \mathrm{~h}$ on day 1 of admission or even more frequently in the case of clinical deterioration and necessity for ICU admission. NOM failed in 2 patients $(7.7 \%)$ operated on due to worsening of abdominal pain and hypovolemic shock. No patient developed complications related to the spleen and there were no deaths in this series [8]. According to these findings, many experts recommend a continuous monitoring of at least blood pressure, heart rate and respiratory rate, as well as continuous pulse oximetry during the first days of admission.

\section{Haemoglobin measurement}

Post-injury haemoglobin measurement is another unsolved issue in NOM. Parks et al. reviewed NOM guidelines for blunt abdominal liver injuries. Safety and optimal LOS were evaluated solely based on clinical criteria. They suggested serial haemoglobin measurements every $6 \mathrm{~h}$ for the first $24 \mathrm{~h}$ in stable patients with grade I-II lesions before discharging patients if they remained stable. In grade III-V injuries they recommended measurements every $6 \mathrm{~h}$ during the first $12 \mathrm{~h}$, and after every $12 \mathrm{~h}$ thereafter [12]. Gomez et al. reported that $85 \%$ of the experts answering a questionnaire concerning haemoglobin monitoring would evaluate values every $8-12 \mathrm{~h}$ in NOM of isolated grade II blunt splenic injuries for the time during which the patient is in the ICU [9]. Olthof et al. showed that all experts who participated in their survey perform serial measurement: in the first $24 \mathrm{~h}$ every $4-6 \mathrm{~h}$, and every $12-24 \mathrm{~h}$ thereafter [23]. Consensus regarding this topic could not be reached until now, but most experts suggest close haemoglobin controls at least every $12 \mathrm{~h}$ during the first 3 days after trauma, followed by monitoring every $24 \mathrm{~h}$ until discharge.
Experts recommend continuous monitoring of blood pressure, heart rate, oxygen saturation and respiratory rate early after admission

Experts suggest haemoglobin controls every $12 \mathrm{~h}$ during the first 3 days and every $24 \mathrm{~h}$ thereafter 


\begin{tabular}{|c|c|c|c|}
\hline & Comment & References & $\begin{array}{l}\text { Highest } \\
\text { grade of } \\
\text { evidence }\end{array}$ \\
\hline Transfusion trigger & $\begin{array}{l}>2 \text { units of packed red blood cells limit NOM and determine } \\
\text { need for OM; conservative treatment may be only contin- } \\
\text { ued if transfusion requirements are due to other associated } \\
\text { injuries }\end{array}$ & {$[23,39]$} & $2 a$ \\
\hline Length of stay & $\begin{array}{l}\text { Hospital stay is recommended at least for } 2 \text { (grade I-II) } \\
\text { and } 4 \text { (grade III-VI) days, after at least } 72 \mathrm{~h} \text { of admission } \\
\text { to a monitored setting, continuous evaluation of vital signs } \\
\text { and haemoglobin. Initial admission to ICU is decided upon } \\
\text { clinical judgement }\end{array}$ & {$[8,23,27,33,40]$} & $2 a$ \\
\hline \multirow[t]{2}{*}{ Usual/daily activity } & For grade I-III lesions allowed after 2 weeks & \multirow[t]{2}{*}[31,34,41]{} & \multirow[t]{2}{*}{$2 c$} \\
\hline & For grade IV-VI lesions allowed after 6 weeks & & \\
\hline \multirow[t]{2}{*}{ Moderate activity } & For grade I-III lesions allowed after 2 months & \multirow[t]{2}{*}[31,34,41]{} & \multirow[t]{2}{*}{$2 c$} \\
\hline & For grade IV-VI lesions allowed after 6 months & & \\
\hline \multirow[t]{2}{*}{ Contact sports } & For grade I-III lesions allowed after 6 months & \multirow[t]{2}{*}[31,34,41]{} & \multirow[t]{2}{*}{$2 c$} \\
\hline & For grade IV-VI lesions allowed after 12 months & & \\
\hline $\begin{array}{l}\text { Post-splenectomy vaccines against encapsu- } \\
\text { lated bacteria }\end{array}$ & $\begin{array}{l}\text { Immunization is recommended } 2-4 \text { weeks after splenec- } \\
\text { tomy }\end{array}$ & {$[42,43]$} & $1 a$ \\
\hline $\begin{array}{l}\text { Post-embolisation vaccines against encapsu- } \\
\text { lated bacteria }\end{array}$ & $\begin{array}{l}\text { Immunization for patients with splenic injuries managed } \\
\text { conservatively is not recommended }\end{array}$ & {$[44,45,46]$} & $2 a$ \\
\hline
\end{tabular}

For daily practice, transfusion of more than two blood unit cells limits NOM and determines the need for OM

Patients selected for NOM should be monitored continuously

\section{Number of transfused blood units}

The EAST guideline considers that a high number of blood units transfused early after admission might contraindicate NOM in blunt hepatic or splenic injuries, although there is limited evidence on defined cut-off levels for conversion to surgical treatment $[10,11]$. Patients who failed NOM received more blood bags during hospitalization than those who underwent successful conservative treatment. No consensus statement on the number of blood units that contraindicate NOM could be reached [27]. According to Olthof et al., transfusion of five or more units of blood could be a sensible cut-off to guide the decision to operative or perform angiographic intervention [23].

Risk of transfusion-related diseases has led to further discussion and controversy regarding the use of blood products in the treatment of splenic and liver injuries. Luna and Dellinger suggested that the risk of death due to blood transfusion in successful NOM of splenic injury exceeds that of immediate splenectomy, stating thast two blood units in isolated spleen injury limit NOM and conservative treatment may only be continued if transfusion requirements are due to other associated injuries [39]. For daily practice, it could be concluded that transfusion of more than two blood unit cells limits NOM and determines the need for operative management (OM).

\section{Hospital discharge and ICU admission}

There are currently no clear recommendations regarding a minimum observation period after blunt splenic and/or liver trauma, neither in the ICU nor on the ward. Recent studies reported that clinical judgment is the predominant aspect for decision-making [40]. In the survey conducted by Olthof et al., all participating experts agreed that the most relevant factors are vital signs and haemoglobin [23]. In a retrospective study performed by Fernandes et al., charts of all patients with splenic injury were reviewed and patients with grade IV lesions treated non-operatively were included in the analysis. LOS was about 5-9 days [8]. Peitzman et al. recommend intensive monitoring for 1 to 3 days, and 3 to 5 days stay on the ward thereafter [27]. A shorter length of stay with successful discharge of patients with low-grade injuries after 1 to 2 days and after 3 to 4 days for higher-grade injuries has also been reported [23]. EAST has not set any recommendations regarding LOS [32]. Additionally, there are no published prospective data about the timing of safe discharge. For clinical practice, patients selected for NOM should be monitored continuously, some institutional protocols state that all patients with blunt hepatic and splenic injury should be admitted to the ICU [8]. In the survey by Olthof, $100 \%$ of the experts administered continuous monitoring, $63 \%$ of them in the ICU [23]; $96 \%$ agreed to keep monitoring for at least 3 days [33]. To date, clinical judgement still remains the most relevant aspect. 


\section{Bed rest and return to activity}

Many surgeons still believe that early mobilisation of patients with blunt solid organ injuries increases the risk of delayed haemorrhage. According to London et al. [34], long periods in bed are unnecessary, since the time of mobilisation after blunt organ injuries does not contribute to late bleeding. In a retrospective cohort study of hepatic injuries, the median day of post-trauma mobilisation was day 2; $30 \%$ of patients had been mobilised after the first hospital day, $66 \%$ on the second and $80 \%$ on the third day. No patients failed NOM as a result of a secondary bleeding event from hepatic injuries. Patients with blunt splenic injury were mobilised on median day 3 ; $17 \%$ had been mobilised on the first day, $50 \%$ on the second and $77 \%$ on the third day. There was no significant difference regarding those who failed NOM due to bleeding upon comparing early versus late mobilisation. Hence, the findings in this retrospective analysis show that the day of first mobilisation was not associated with an increased incidence of delayed rupture. On the contrary, there may be significant benefits of early mobilisation such as reduced hospital LOS and reduced resource utilization [34], as well as lower rates of pneumonia, deep vein thrombosis (DVT) and pulmonary embolism [41]. Summarising, early mobilisation on day 2 or 3 after blunt hepatic or splenic injuries should be achieved in clinically stable patients.

The EAST guideline does not address the issue of return to activities after hepatic and splenic trauma, probably highlighting the lack of consensus in the literature $[10,11]$. Fata et al. reported considerable variation of recommendations for high-grade injuries present among experts. For grade III, IV and V injuries, nearly half of experts would allow return to mild activities within 4 to 6 weeks and to full activities within 2 to 3 months. However, the other half of surveyed participants recommended restricted activities for a period of 4-6 and 5\% for more than 6 months [40]. This clearly emphasizes a lack of evidence. Restitution of a simple liver laceration and sub-capsular hematoma occurs within 2 to 4 months, whereas complex injuries require up to 6 months [47]. Some experts recommend return to unrestricted activity only after a normalised CT, usually 3 to 6 months after injury [48]. Most authors relate the recommendation of reduced activity to the severity of injury. Available published data suggest safety of return to unrestricted activity after splenic trauma between 3 weeks to even 6 months, depending on the severity of the injuries. Clinical judgment represents the key determinant [48].

\section{Oral intake}

The return to normal diet is critical in trauma patients. The guidelines state that issues on early oral feeding are still unsettled in the literature $[10,11]$. Gomez et al. mentioned that $71 \%$ of experts initiate oral diet in clinically stable patients after $24 \mathrm{~h}$ of trauma onset [9].

\section{Prophylaxis of thromboembolic events}

DVT prophylaxis with low-molecular weight heparin (LMWH) is essential in the management of patients with blunt liver or spleen injuries. In a retrospective analysis conducted in the Regional Trauma Unit of the Sunnybrook Health Science Centre, the largest level 1 trauma facility for adults in Canada, serial impedance plethysmography and lower-extremity contrast venography were performed to detect DVT in a cohort of 716 patients. From January 1989 through April 1991, patients with major trauma were prospectively evaluated with objective diagnostic testing for venous thromboembolism. DVT in the lower extremities was found in 201 of the 349 patients (58\%) without any DVT prophylaxis after trauma. Pulmonary embolism was confirmed in 7 patients [37]. Currently, the optimal DVT prophylaxis strategy for trauma patients with a higher risk of bleeding is unknown. The American College of Chest Physicians recommends early initiation of DVT prophylaxis to reduce the incidence of thromboembolic complications [38]. EAST also supports the practice of early DVT prophylaxis for solid organ injuries. However, these recommendations lack a definition of the optimal timing for initiation of DVT prophylaxis [28]. Despite some evidence that pharmacological prophylaxis for DVT does not negatively interfere with $\mathrm{NOM}$, there is no consensus regarding the safest timepoint for its commencement after trauma $[10,11]$. In a retrospective study performed by Rostas et al., early use of LMWH during the first $48 \mathrm{~h}$ of hospitalization was not associated with bleeding and NOM failure [49]. Another study also suggested that the use of LMWH in the first $48-72 \mathrm{~h}$ of admission was not associated with increased blood transfusion rate or NOM failure [42]. Joseph et al. [43] detected no significant correlation between early anticoagulation and bleeding complications in a North American cohort of patients with blunt abdominal solid organ injuries. Hence, to gain high-
Early mobilisation on day 2 or 3 after blunt hepatic or splenic injuries is achievable in clinically stable patients

The recommended period of reduced activity is related to the severity of injury

Early initiation of DVT prophylaxis is recommended to reduce the incidence of thromboembolic complications 
Early prophylaxis of thromboembolic events may be a safe option in trauma patients with blunt injury of a solid organ

Vaccines against encapsulated bacteria should be administered 2 weeks before or 2-4 weeks after (elective) splenectomy

\section{Splenic immune function of embolised patients seems to be preserved}

quality evidence, prospective studies are required to define the impact of early (within $48 \mathrm{~h}$ after trauma) DVT prophylaxis, stratified according to the grade of injury. For clinical practice, early prophylaxis of thromboembolic events may be a safe option in trauma patients with blunt solid organ injury and could be started in the first $48-72 \mathrm{~h}$ after trauma.

\section{Post-splenectomy and post-embolisation vaccination}

Overwhelming post-splenectomy infection (OPSI) is a very serious condition that can progress from mild symptoms to fulminant sepsis in a short period of time. Patients who are asplenic or hyposplenic have an increased lifetime risk of OPSI and death, particularly from encapsulated organisms like Streptococcus pneumonia, Haemophilus influenzae and Neisseria meningitidis [44]. The spleen has specialised lymphoid tissue, including splenic macrophages, that effectively attack these encapsulated organisms. Currently, it is established and recommended that vaccines against these bacteria should be administered either 2 weeks before or 2 to 4 weeks after (elective) splenectomy to increase the immunological benefit. Lifelong prophylactic antibiotics should be offered and started in case of any bacterial infection [45]. Routine immunization for patients with splenic injuries managed conservatively without splenectomy is not recommended. Although concerns have been raised about splenic immune function after NOM with or without splenic angioembolisation, evidence seems to be emerging that immune function is well preserved [46]. A retrospective analysis performed by Tominaga et al. suggested that the immunologic profile of embolised patients is similar to controls [35]. Olthof et al. compared the splenic immune function of patients who were embolised with splenectomised patients and healthy controls. The splenic immune function of embolised patients was preserved, therefore routine vaccination appears not to be indicated [50].

Both retrospective studies support the safe use of splenic embolisation with sustained immune function without a need for vaccination. Concluding, immunisation after splenectomy should be recommended, not, however, after embolisation.

\section{Repeat imaging}

The accuracy of abdominal CT in diagnosing liver trauma excluding other injuries plays a central role in achieving successful NOM. The question of routine follow-up imaging for blunt abdominal trauma has been widely debated. Clancy et al. published that patients with higher-grade injuries were more likely to receive follow-up imaging during their period of hospital admission. CT imaging within $72 \mathrm{~h}$ in all grades of splenic injury might be indicated, based on reports documenting the detection of splenic artery pseudoaneurysm even in low-grade injuries. Factors predicting this pathology are not available. The authors suggest ultrasound instead of CT scans in young patients with grade I and II injuries, based on clinical judgment [51]. CT scans repeated after more than 10 days following initial presentation do not have a substantial influence on patient treatment [36]. The utility of routine follow-up CT scans after blunt hepatic trauma initially managed non-operatively has been evaluated in many studies. Navarro et al. suggested that in asymptomatic paediatric patients, CT follow-up studies do not provide additional information for clinical management guidance. Therefore, routine follow-up imaging studies seem of limited value [48]. Although CT-based documentation of complete organ recovery was once standard of care, follow-up CT is no longer recommended unless clinically indicated [48]. Lynch et al. reported that CT-documented injury was identified by ultrasound for all of the investigated patients; all returned to full activity with no long-term complications after ultrasound demonstrated healing [52]. The main argument for follow-up imaging is delayed splenic rupture. Radiographic healing may under- or overestimate physiologic healing [48]. Therefore, routine radiological follow-up of blunt splenic injury does not necessarily identify patients at risk nor does it help to guide a recommendation for return to full activity after an appropriate time of restriction. In another retrospective study by Allins et al., none of the follow-up scans showed major progression of injury. The authors therefore concluded that these scans did not influence decision-making for a change to surgery in any of the patients and are therefore unnecessary. Hence, routine followup CT scanning should not be part of NOM protocols for blunt liver and splenic injuries [53].

\section{Practical conclusion}

Hepatic and splenic injuries are common and NOM shows increasing popularity although good evidence, i.e., from well-designed prospective trials, is lacking. Especially questions relating to 
daily life (return to activity, follow-up, bed rest, LMWH treatment) remain controversial. Developing protocols and regular auditing might be the first steps to successfully achieving better outcomes and avoiding unnecessary surgery with all its long-term consequences. Nevertheless, surgery at the right time is still the right choice to save a patient's life. The use of standardized operating procedures (SOPs) to drive NOM of blunt hepatic and splenic injuries is uncommon in many centres, leading to a high number of different management pathways, even among surgeons working in the same hospital. SOPs could help to triage appropriate patients for either continuous monitoring or therapeutic intervention. There is emerging evidence that the use of strict protocols for NOM of hepatic and splenic injuries might increase overall success rates, thus avoiding unnecessary operations.

\section{Corresponding address}

\section{Univ.-Prof. Dr. D. Öfner, MAS, MSc., FACS}

Department of Visceral, Transplantation and Thoracic Surgery, Medical University of Innsbruck Anichstraße 35, 6020 Innsbruck, Austria dietmar.oefner@i-med.ac.at

Funding. Open access funding provided by University of Innsbruck and Medical University of Innsbruck.

Conflict of interest. M. Fodor, F. Primavesi, D. Morell-Hofert, M. Haselbacher, E. Braunwarth, B. Cardini, E. Gassner, D. Öfner and S. Stättner declare that they have no competing interests.

Open Access This article is distributed under the terms of the Creative Commons Attribution 4.0 International License (http:// creativecommons.org/licenses/by/4.0/), which permits unrestricted use, distribution, and reproduction in any medium, provided you give appropriate credit to the original author(s) and the source, provide a link to the Creative Commons license, and indicate if changes were made.

\section{References}

1. Poole GV, Ward EF, Muakkassa FF, Hsu HS, Griswold JA, Rhodes RS. Pelvic fracture from major blunt trauma. Outcome is determined by associated injuries. Ann Surg. 1991;213(6):532-8. discussion 8-9.

2. Kornprat $P$, Uranues $S$, Salehi B, Hoebarth G, Buchinger W, Kuttnig $M$, et al. Preliminary results of a prospective study of nonoperative treatment of splenic injuries caused by blunt abdominal trauma. Eur Surg. 2007;39(1):33-8.

3. Raza M, Abbas Y, Devi V, Prasad

KV, Rizk KN, Nair PP. Non operative management of abdominal trauma - a 10 years review. World J Emerg Surg. 2013;8:14.

4. Cirocchi R, Boselli C, Corsi A, Farinella E, Listorti C, TrastulliS, et al. Is non-operative management safe and effective for all splenic blunt trauma? A systematic review. Crit Care. 2013;17(5):R185.

5. van derVlies $\mathrm{CH}$, OlthofDC, Gaakeer $\mathrm{M}$, Ponsen KJ, van Delden OM, Goslings JC. Changing patterns in diagnostic strategies and the treatment of blunt injury to solid abdominal organs. Int J Emerg Med. 2011;4:47

6. Lucas CE, Ledgerwood AM. Changing times and the treatment of liver injury. Am Surg. 2000;66(4):337-41.

7. Cogbill TH, Moore EE, Jurkovich GJ, Morris JA, Mucha P, Shackford SR, et al. Nonoperative management of blunt splenic trauma: a multicenter experience. J Trauma. 1989;29(10):1312-7.
8. Fernandes $T M$, Dorigatti $A E$, Pereira BM, Cruvinel Neto J, Zago TM, Fraga GP. Nonoperative management of splenic injury grade IV is safe using rigid protocol. Rev Col Bras Cir. 2013;40(4):323-9.

9. Gomez D, Haas B, Al-Ali K, Monneuse $O$, Nathens $A B$, Ahmed $\mathrm{N}$. Controversies in the management of splenic trauma. Injury. 2012;43(1):55-61.

10. Stassen NA, Bhullar I, Cheng JD, Crandall $M$, Friese R, Guillamondegui $\mathrm{O}$, et al. Nonoperative management of blunt hepatic injury: an Eastern Association for the Surgery of Trauma practice management guideline. J Trauma Acute Care Surg. 2012;73(5 Suppl 4):S288-S93.

11. Stassen NA, Bhullar I, Cheng JD, Crandall ML, Friese RS, Guillamondegui OD, et al. Selective nonoperative management of blunt splenic injury: an Eastern Association for the Surgery of Trauma practice management guideline. J Trauma Acute Care Surg. 2012;73(5 Suppl 4):S294-S300.

12. Coccolini F, Montori G, Catena F, Di Saverio S, Biffl W, Moore EE, et al. Liver trauma: WSES position paper. World J Emerg Surg. 2015;10:39.

13. Coccolini F, Montori G, Catena F, Kluger Y, Biffl W, Moore EE, et al. Splenic trauma: WSES classification and guidelines for adult and pediatric patients. World J Emerg Surg. 2017;12:40.

14. Oniscu GC, Parks RW, Garden OJ. Classification of liver and pancreatic trauma. HPB (Oxford). 2006;8(1):4-9.

15. Tinkoff G, Esposito TJ, Reed J, Kilgo $P$, Fildes J, Pasquale $M$ et al. American Association for the Surgery of Trauma Organ Injury Scale I: spleen, liver, and kidney, validation based on the National Trauma Data Bank. J Am Coll Surg. 2008;207(5):646-55.

16. Moore EE, Moore FA. American Association for the Surgery of Trauma Organ Injury Scaling: 50th anniversary review article of the Journal of Trauma. J Trauma. 2010;69(6):1600-1.

17. Moore EE, Shackford SR, Pachter $\mathrm{HL}$, McAninch JW, Browner BD, Champion HR, et al. Organ injury scaling: spleen, liver, and kidney. J Trauma. 1989;29(12):1664-6.

18. Mirvis SE, Whitley NO, Vainwright JR, Gens DR. Blunt hepatic trauma in adults: CT-based classification and correlation with prognosis and treatment. Radiology. 1989;171(1):27-32.

19. Piper GL, Peitzman AB. Current management of hepatic trauma. Surg Clin North Am 2010;90(4):775-85.

20. Sampanis D, Siori M. Surgical use of fibrin glue-coated collagen patch for non-hemostaticindications. Eur Surg. 2016;48(5):262-8.

21. Kohn JS, Clark DE, Isler RJ, Pope CF. Is computed tomographic grading of splenic injury useful in the nonsurgical management of blunt trauma? J Trauma. 1994;36(3):385-9. discussion 90. 
22. Sutyak JP, Chiu WC, D'Amelio LF, Amorosa JK, Hammond JS. Computed tomography is inaccurate in estimating the severity of adult splenic injury. J Trauma. 1995;39(3):514-8.

23. Olthof $D C$, Joosse $P$, van der Vlies $\mathrm{CH}$, de Haan RJ, Goslings JC. Prognostic factors for failure of nonoperative management in adults with blunt splenic injury: a systematic review. JTrauma Acute Care Surg. 2013;74(2):546-57.

24. Malhotra AK, Latifi R, Fabian TC, Ivatury RR, Dhage $S$, Bee TK, et al. Multiplicity of solid organ injury: influence on management and outcomes after blunt abdominal trauma. J Trauma. 2003;54(5):925-9.

25. Hsieh TM, Cheng Tsai T, Liang JL, Lin CC. Non-operative management attempted for selective high grade blunt hepatosplenic trauma is a feasible strategy. World J Emerg Surg. 2014;9(1):51.

26. Yanar H, Ertekin C, Taviloglu K, Kabay B, Bakkaloglu H, Guloglu R. Nonoperative treatment of multiple intra-abdominal solid organ injury after blunt abdominal trauma. JTrauma. 2008;64(4):943-8.

27. Peitzman $A B$, Heil $B$, Rivera $L$, Federle MB, Harbrecht BG, Clancy $K D$, et al. Blunt splenic injury in adults: multi-institutional Study of the Eastern Association for the Surgery of Trauma. J Trauma. 2000:49(2):177-87. discussion 87-9.

28. Zarzaur BL, Kozar RA, Fabian TC, CoimbraR. A survey of American Association for the Surgery of Trauma member practices in the management of blunt splenic injury. JTrauma. 2011;70(5):1026-31.

29. Afifi RY. Blunt abdominal trauma: back to clinical judgement in the era of modern technology. Int J Surg. 2008:6(2):91-5.

30. Schurink GW, Bode PJ, van Luijt PA, van Vugt $A B$. The value of physical examination in the diagnosis of patients with blunt abdominal trauma: a retrospective study. njury. 1997;28(4):261-5.

31. Ferrera PC, Verdile VP, Bartfield JM, Snyder HS, Salluzzo RF. Injuries distracting from intraabdominal injuries after blunt trauma. Am Emerg Med. 1998;16(2):145-9.

32. Prieto $M$, Gómez MD, Berenguer M, Córdoba J, Rayón JM, Pastor $M$, et al. De novo hepatitis $B$ after liver transplantation from hepatitis B core antibody-positive donors in an area with high prevalence of anti-HBc positivity in the donor population. Liver Transpl. 2001;7(1):51-8.

33. Carlotto JR, Lopes-Filho GeJ, Colleoni-Neto R. Main controversies in the nonoperative management of blunt splenic injuries. Arq Bras Cir Dig. 2016;29(1):60-4.

34. London JA, Parry L, Galante J, Battistella F. Safety of early mobilization of patients with blunt solid organ injuries. Arch Surg. 2008;143(10):972-6. discussion 7.

35. Tominaga GT, Simon FJ, Dandan IS Schaffer KB, Kraus JF, Kan M, et al. Immunologic function after splenic embolization, is there a difference? JTrauma. 2009;67(2):289-95.

36. Lawson DE, Jacobson JA, Spizarny DL, Pranikoff T. Splenic trauma: value of follow-up CT. Radiology. 1995;194(1):97-100.

37. Geerts WH, Code Kl, Jay RM, Chen E, Szalai JP. A prospective study of venous thromboembolism after major trauma. N Engl J Med. 1994;331(24):1601-6.

38. Guyatt GH, Akl EA, Crowther M Gutterman DD, Schuünemann $\mathrm{HJ}$, Panel ACoCPATaPoT. Executive summary: antithrombotic therapy and prevention of thrombosis, 9th ed: American College of Chest Physicians Evidence-Based Clinical Practice Guidelines. Chest. 2012;141(2 Suppl):7S-47S.

39. Luna GK, Dellinger EP. Nonoperative observation therapy for splenic injuries: a safe therapeutic option? Am J Surg. 1987;153(5):462-8

40. Fata P, Robinson L, Fakhry SM. A survey of EAST member practices in blunt splenic injury: a description of current trends and opportunities for improvement. J Trauma. 2005;59(4):836-41. discussion $41-2$.

41. Von Rueden KT, Harris JR. Pulmonary dysfunction related to immobility in the trauma patient. AACN Clin Issues. 1995;6(2):212-28.

42. Eberle BM, Schnüriger $B$, Inaba $K$ Cestero R, Kobayashi L, Barmparas $\mathrm{G}$, et al. Thromboembolic prophylaxis with low-molecular-weight heparin in patients with blunt solid abdominal organ injuries undergoing nonoperative management: current practice and outcomes. J Trauma. 2011;70(1):141-6. discussion 7.

43. Joseph B, Pandit V, Harrison C, Lubin D, Kulvatunyou N, Zangbar $B$, et al. Early thromboembolic prophylaxis in patients with blunt solid abdominal organ injuries undergoing nonoperative management: is it safe? Am J Surg 2015;209(1):194-8.

44. Morgan TL, Tomich EB. Overwhelming post-splenectomy infection (OPSI): a case report and review of the literature. J Emerg Med. 2012;43(4):758-63.

45. Hildebrand DR, Ben-Sassi A, Ross NP, Macvicar R, Frizelle FA, Watso AJ. Modern management of splenic trauma. BMJ. 2014;348:g1864.

46. Skattum J, Naess PA, Gaarder C. Non-operative management and immune function after splenic injury. Br J Surg. 2012;99(Suppl 1):59-65.

47. Tiberio GA, Portolani N, Coniglio A, Piardi T, Dester SE, Cerea K, et Evaluation of the healing time of non-operatively managed liver injuries. Hepatogastroenterology. 2008:55(84):1010-2.

48. Juyia RF, Kerr HA. Return to play after liver and spleen trauma. Sports Health. 2014;6(3):239-45.

49. Rostas JW, Manley J, Gonzalez RP Brevard SB, Ahmed N, Frotan MA, et al. The safety of low molecularweight heparin after blunt liver and spleen injuries. Am J Surg. 2015;210(1):31-4.

50. Olthof DC, Lammers AJ, van Leeuwen EM, Hoekstra JB, ten Berge IJ, Goslings JC. Antibody response to a T-cell-independent antigen is preserved after splenic artery embolization for trauma. Clin Vaccine Immunol. 2014;21(11):1500-4.

51. Clancy AA, Tiruta C, Ashman D, Ball CG, Kirkpatrick AW. The song remains the same although the instruments are changing: complications following selective nonoperative management of blunt spleen trauma: a retrospective review of patients at a level I trauma centre from 1996 to 2007. J Trauma Manag Outcomes. 2012;6(1):4.

52. Lynch JM, Meza MP, Newman B, Gardner MJ, Albanese CT. Computed tomography grade of splenic injury is predictive of the time required for radiographic healing. J Pediatr Surg. 1997:32(7):1093-5. discussion 5-6.

53. Allins $A, H o T$, Nguyen $T H$, Cohen M, Waxman K, Hiatt JR. Limited value of routine followup CT scans in nonoperative management of blunt liver and splenic injuries. Am Surg. 1996;62(11):883-6. 


\section{DFP-Literaturstudium}

Bitte beachten Sie:

Im Rahmen des Diplom-Fortbildungsprogramms ist es möglich, durch das Literaturstudium in der

European Surgery Punkte für das DFP zu erwerben.

1. Nach der Lektüre des DFP-Artikels beantworten Sie bitte die Multiple-ChoiceFragen. Eine Frage gilt dann als richtig beantwortet, wenn alle möglichen richtigen Antworten angekreuzt sind. Bei positiver Bewertung (66 Prozent der Fragen) werden Ihnen drei DFP-Fachpunkte zuerkannt.

\section{DFP-Fragen}

? Blunt abdominal trauma of liver and spleen: which answer is correct?

O Blunt abdominal trauma is not very frequent in central European emergency departments.

Abdominal organs are involved in $10 \%$ of polytrauma patients, with an occurrence of hepatic and splenic injuries in 5 and $5 \%$, respectively.

O The only possible therapeutic strategy is surgical treatment.

Due to frequent postoperative complications after primary surgical treatment in the past, a paradigm shift to non-operative management (NOM) in haemodynamically stable patients has emerged in major trauma centres.

O Regarding therapeutic laparotomies, evidence has shown additional advantages such as less frequent need for blood transfusions, lower mortality rates and lower healthcare costs compared with conservative treatment

? The Moore scoring system is considered the gold standard to describe hepatic and splenic injuries: which answer is correct?

O This classification scheme is an anatomic description scaled from I to VI for the spleen and from I to VIII for the liver, representing minimal to the most severe injury.

O Most liver injuries are grade IV or V and are successfully treated conservatively.
2. Schicken Sie diese Seite entweder per Post oder Fax an die Redaktion von Springer Medizin Wien (z. Hd. Susanna Hinterberger), Prinz-EugenStraße 8-10, 1040 Wien, Postfach 11, Fax: 01 / 3302426

3. Einsendeschluss: 20.02.2019

O Laceration involving segmental or hilar vessels producing major devascularisation ( $>25 \%$ of spleen) in splenic injuries is described as Moore grade IV.

O For multiple injuries, two grades should be advanced in the classification system, up to grade III.

The Moore score is based on the Organ Injury Scale (OIS) of the American Association for Surgery of Trauma (AAST) and was published in 2000.

\section{? Bed rest and return to activity after} blunt hepatic and splenic injuries: which answer is correct?

O Many surgeons still believe that early mobilisation of patients with blunt solid organ injuries increases the risk of delayed haemorrhage.

The guidelines report clear recommendations concerning the issue of return to activities after hepatic and splenic trauma.

O Restitution of a simple liver laceration and sub-capsular hematoma occurs within 8 to 10 months, whereas complex injuries require up to 12 months.

O For grade III, IV and V injuries, nearly half of experts would allow return to full activities within 2 to 3 weeks.

O Some experts recommend return to unrestricted activity only after a normalised computer tomography (CT), usually 1 to 3 months after injury.
4. Internet: Sie haben die Möglichkeit, den Fragebogen unter www.SpringerMedizin.at/fortbildung/ herunterzuladen oder unter E-Learning auf der Website der Österreichischen Akademie der Ärzte www.meindfp.at auszufüllen.
Post-splenectomy and post-embolisation vaccination: which answer is correct?

Overwhelming post-splenectomy infection (OPSI) is a mild condition that rarely causes complications like fulminant sepsis.

O Patients who are asplenic or hyposplenic have an increased lifetime risk of OPSI and death especially from encapsulated organisms like Pseudomonas aeruginosa or Escherichia coli.

O Currently, it is established and recommended that vaccines against these bacteria should be administered either 4 weeks before or 8 to 10 weeks after (elective) splenectomy.

O Routine immunization for patients with splenic injuries managed conservatively without splenectomy is also recommended.

O Retrospective studies analysed the splenic immune function of embolised patients and concluded that routine vaccination appears not indicated, because splenic immune function was preserved.

Repeat imaging: which answer is correct?

O CT scans repeated after more than 2 weeks following initial presentation have a substantial influence on patient treatment.

O Many authors suggest ultrasound instead of CT scans in young patients with grade I and II splenic injuries. 
O Routine follow-up CT scanning is considered an integrated part of NOM protocols for blunt liver and splenic injuries.

O In asymptomatic paediatric patients, CT follow-up studies always provide additional information for clinical management guidance.

Routine radiological follow-up of blunt splenic injury always helps to guide a recommendation for return to full activity.

Name:

Straße/Gasse:

Ort/PLZ:

Telefon: 